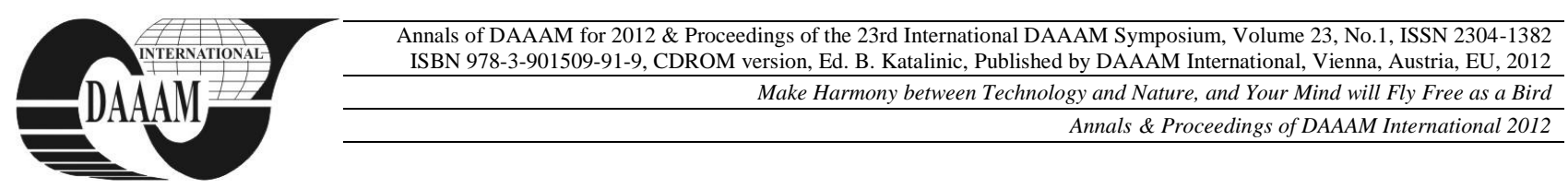

\title{
OFFICE PRINT-OUTS IN THE PRODUCTION OF RECYCLED FOOD PACKAGING PAPER
}

\author{
JAMNICKI, S[onja]; MAJNARIC, I[gor] \& BOLANCA MIRKOVIC, I[vana]
}

\begin{abstract}
The possibility of using recovered office paper grades as alternative raw material in the manufacture of white top plies of food packaging linerboards is a major area of investigation. Three different types of office print-outs had been submitted to a chemical deinking flotation and the handsheets formed after each deinking flotation trial were analyzed on the presence of residual chemical contaminants: heavy metals $(\mathrm{Cd}$, $\mathrm{Pb}, \mathrm{Hg}$ ), primary aromatic amines, phthalates, diisopropylnaphthalenes (DIPN) and polychlorinated biphenyls $(P C B)$. Moreover, bleed fastness of fluorescent whitened agents (FWA) was determined as well. The conducted research showed that of all analyzed contaminants in the deinked pulp handsheets, only phthalates were detected, in concentrations from 5.3 up to $12.5 \mathrm{mg} / \mathrm{kg}$ of paper. However, according to present toxicological assessments, these amounts of detected phthalates do not impose a health risk to the consumers. Research thus demonstrated that all tested papers regarding the analyses done within this study are proved suitable to be used in direct contact with food.
\end{abstract}

Keywords: Office print-outs, deinking flotation, white top linerboards, food packaging, chemical contaminants

\section{INTRODUCTION}

Deinking flotation is the most common method of removing printing ink from recovered papers during the recycling process. It is successful for most of today's inks and printing technologies which can be found in recovered papers [1].

White top linerboards used in food packaging applications are manufactured largely on the basis of recovered paper. Either virgin fiber pulps or recovered papers of medium and higher grades are used to manufacture white top plies of multi-ply testliners [2]. In Croatia, the linerboard's white top ply is usually produced form deinked pulp originating from offset printed wood-free papers. This means that the layer intended to come into direct contact with food is manufactured from deinked fiber furnish.

On the other side, office print-outs are mostly used in the production of tissue paper, writing and printing paper, paperboard and newsprint [3,4] but so far rarely or never used as fibrous raw materials for the production of linerboard's top ply. Moreover, the research has shown that office printing has increased by 56\% between 1996 and 2003 in the world's five biggest economies. In Europe, the demand for A4 paper reached 5 million tonnes in 2006 [5]. The objective of this study was therefore to determine the possibilities of use of office print-outs as suitable recovered paper source for the production of white top linerboards.
Food contact materials, including recycled fiber-based paper, have to comply with a basic set of criteria concerning safety. This means that recycled paper for food contact should not give rise to migration of substances which can endanger human health. This requirement comes from the EU Framework Regulation (EC) No 1935/2004 that covers all materials which come in direct contact with food [6]. However, besides general requirements laid out in the Framework Regulation, food packaging materials made from paper and board are not yet covered by harmonized European legislation. In the absence of a specific directive, the paper and board food packaging supply chain relies on the national legislation for paper and board published in the Netherlands, Italy and France or the BfR Recommendation XXXVI [7] published in Germany. Existing regulations define the chemicals that are allowed in the manufacture of paper and board and set limits for various contaminants (heavy metals, phthalates, polychlorinated biphenyls, etc.) in finished products [8]. In Croatia, paper and board food contact materials are regulated by the Ordinance on sanitary safety of materials and articles intended to come into direct contact with foodstuffs [9]. However, in addition to current national laws and existing regulations for paper and board food contact materials, guideline documents such as Nordic report on paper and board food contact materials developed by the Nordic Council of Ministers can also be found [10]. Such documents concern manufacturers of paper and board materials and articles intended for food contact and are designed to provide guidance for establishing compliance with the Regulation (EC) No 1935/2004.

In this study, three different types of office print-outs were submitted to a chemical deinking flotation and the handsheets formed after each deinking flotation trial were tested on the suitability for food contact. Food contact analyzes comprised determination of heavy metals $(\mathrm{Cd}, \mathrm{Pb}$, $\mathrm{Hg}$ ), primary aromatic amines, diisopropylnaphthalenes (DIPN), phthalates and polychlorinated biphenyls (PCB) from aqueous or organic solvent extracts of paper samples. The fastness of the fluorescent whitening agents was determined as well. The aim of the study was to investigate the possibility of using office print-outs as an alternative fibre source in the production of white top linerboards used in food packaging applications.

\section{EXPERIMENTAL}

In this experiment, three different types of office printouts were chosen to be recycled by means of laboratory deinking flotation.

Ink jet prints (printed with black pigmented ink), as well as laser prints printed in black and in colour (CMYK) using 
dry toner, were deinked by means of laboratory deinking flotation. Black prints were printed using the Ingede A4 letter Gray Testpage while for colour prints the Ingede A4 letter CMYK Testpage was used.

The Navigator brand office paper was used as a substrate for all printing trials. The office paper characteristics are shown in Table 1.

\begin{tabular}{|l|c|}
\hline Brand & Navigator Universal Office Paper \\
\hline Composition & $\begin{array}{c}72 \% \text { chemical pulp, 20\% fillers, } \\
4 \% \text { binders, 4\% moisture }\end{array}$ \\
\hline Basis weight & $80 \mathrm{gm}^{-2}$ \\
\hline Ash Content & $14.5 \%$ \\
\hline Bulk & $1.31 \mathrm{~cm}^{3} \mathrm{~g}^{-1}$ \\
\hline
\end{tabular}

Tab. 1. Office paper characteristics

Ink jet prints were printed with the Canon iP4300 printer (which uses black pigment-based ink for printing text) and the printing mode was set to text greyscale printing. Laser prints were printed with the HP 1010 printer (for black prints) and colour (CMYK) prints were printed with the LEXMARK C920 printer.

\subsection{Deinking flotation}

For the deinking flotation procedure (Figure 1) three separate recovered paper samples were prepared: black laser prints, colour laser prints and ink jet prints.

The samples were submitted to accelerated ageing for 72 hours at a temperature of $60 \pm 3^{\circ} \mathrm{C}$ prior to the chemical deinking flotation. The samples were then separately recycled following the same routine: 75 grams of absolutely dry paper was cut in $2 \times 2 \mathrm{~cm}$ strips and put in the pulper. By adding two litres of deionised water at a temperature of $60{ }^{\circ} \mathrm{C}$, consistency of pulp was set to $3.75 \%$. Then, the deinking chemicals were added: $5 \% \mathrm{NaOH}(22.90 \mathrm{ml})$, $1.5 \% \mathrm{H}_{2} \mathrm{O}_{2}(20 \mathrm{ml}), 6 \% \mathrm{Na}_{2} \mathrm{SiO}_{3}(17.30 \mathrm{ml}), 0.5 \%$ DTPA $(0.38 \mathrm{~g})$ and $3 \%$ surfactant $(2.25 \mathrm{~g})$. The industrial deinking process was simulated with these amounts of added chemicals. The obtained $\mathrm{pH}$ was between 11.5 and 11.7.

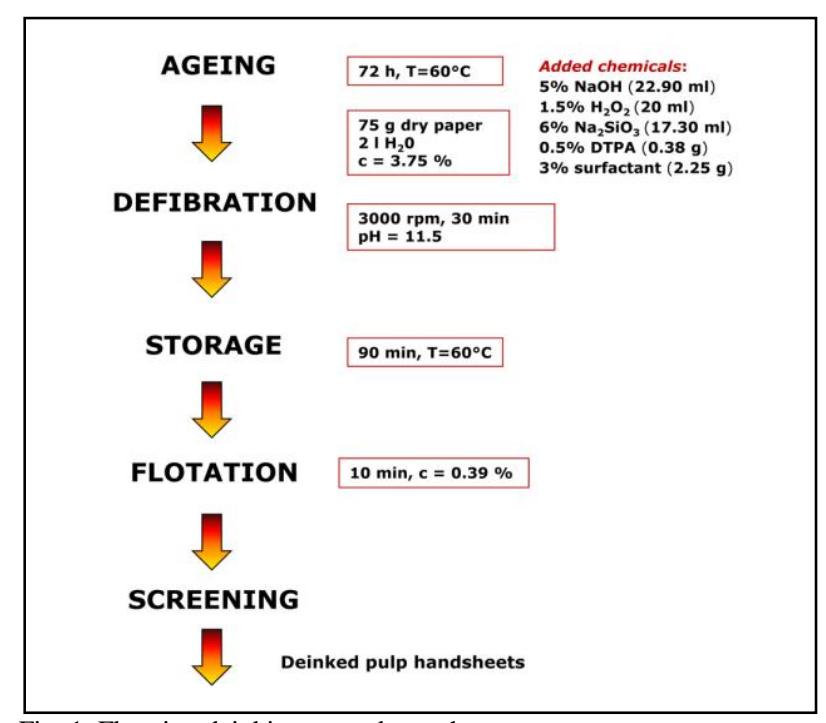

Fig. 1. Flotation deinking procedure scheme

The pulp was disintegrated in the pulper at $3000 \mathrm{rpm}$ for 30 minutes and subsequently stored for 90 minutes at a temperature of $60^{\circ} \mathrm{C}$. The suspension was afterwards diluted with tap water up to the volume of 19 litres and transferred to the flotation cell, where it was flotated for 10 minutes. During the flotation process, the flotation froth was collected manually and removed from the cell. After the flotation, the suspension was screened (poured through a screen/wire mesh) and afterwards diluted with water for the formation of deinked pulp handsheets in accordance with the TAPPI 205 standard [11].

\subsection{Food contact analyses}

Food contact analyses were done on the deinked pulp handsheets formed after conducted deinking flotation on the selected office print-outs as well as on the original office paper. Food contact analyses comprised determination of metal ions $(\mathrm{Cd}, \mathrm{Pb}, \mathrm{Hg})$, primary aromatic amines, diisopropylnaphthalene (DIPN), phthalates and polychlorinated biphenyls (PCB) from aqueous or organic solvent paper extracts. As office paper grades usually contain high amounts of fluorescent whitening agents (FWA), bleed fastness of the FWAs was determined as well.

In order to determine heavy metals, cold-water extracts were prepared from all handsheet and paper samples in accordance with the EN 645:1993 standard [12]. The determination of metal ions $(\mathrm{Cd}, \mathrm{Pb}, \mathrm{Hg})$ in the cold-water extracts was carried out in accordance with the EN 12497 and EN 12498 standards [13, 14]. Metals were detected by means of atomic absorption spectroscopy (AAS).

So as to determine primary aromatic amines, tested paper samples were extracted in dichloromethane. The concentrations of primary aromatic amines (expressed as aniline) in solvent extracts were determined by liquid chromatography-mass spectrometry (LC-MS).

The determination of polychlorinated biphenyls (PCB) was carried out in accordance with the ISO 15318:1999 standard [15]. Paper samples were extracted with boiling ethanolic sodium hydroxide solution. An aliquot of the extract was mixed with water and afterwards subjected to liquid-solid partitioning on a disposable C18 solid phase extraction cartridge followed by elution with hexane. The present PCBs were quantified by means of gas chromatography with electron-capture detection (GC-EDC).

The determination of diisopropylnaphthalene content (DIPN) was carried out in accordance with the standard EN 14719:2005 [16]. The content of total diisopropylnaphthalene (DIPN) was determined by solvent extraction of the paper sample and analyzed by gas chromatography with mass selective detection (GC-MS), using diethylnaphthalene as an internal standard.

For the determination of phthalates, tested paper samples were extracted in dichloromethane. The total phthalate content in solvent extract was determined by gas chromatography with mass selective detection (GC-MS).

The fastness of fluorescent whitened papers (bleed fastness) analysis was performed according to EN 648 [17]. In this test procedure the sample is brought into contact with glass fibre papers previously saturated with a test fluid (food simulant) and placed under load $(1 \mathrm{~kg})$ for a given time period $(24 \mathrm{~h})$. The staining of glass fibre paper was evaluated by comparison with a series of fluorescent whitened comparison papers. Test fluids used were deionised water, diluted acetic acid, soda and olive oil.

The results of conducted analyses were compared to the quantitative restrictions laid down in the German BfR Recommendations (chapter XXXVI) and/or Croatian Ordinance on sanitary safety of materials and articles 
intended to come into direct contact with foodstuff that they had to comply with. However, in case when the German or Croatian regulations did not specify clear limits for tested compounds, the results obtained by chemical analyses were compared with proposed restrictions laid down in the available Nordic guideline - the Nordic report on paper and board food contact materials.

\section{RESULTS AND DISCUSSION}

The results of metal ions determination $(\mathrm{Cd}, \mathrm{Pb}$ and $\mathrm{Hg})$ in the cold-water extracts of tested paper samples are presented in Table 2.

According to the German BfR Recommendations and the Croatian Ordinance on sanitary safety of materials and articles intended to come into direct contact with foodstuffs, the transfer of metal ions into foodstuffs must not exceed $0.5 \mathrm{mg}$ per $\mathrm{kg}$ of paper $(\mathrm{Cd}) ; 3 \mathrm{mg}$ per $\mathrm{kg}$ of paper $(\mathrm{Pb}) ; 0.3$ mg per $\mathrm{kg}$ of paper $(\mathrm{Hg})$.

Testing is not necessary for paper and board intended to come into contact with dry, non-fatty foodstuffs.

\begin{tabular}{|l|c|c|c|}
\hline Amount in water extract & Hg & Cd & Pb \\
\hline & \multicolumn{3}{|c|}{$\mathrm{mg} / \mathrm{kg}$ paper } \\
\hline \multicolumn{1}{|c|}{ Limit } & $\mathbf{0 . 3}$ & $\mathbf{0 . 5}$ & $\mathbf{3}$ \\
\hline Navigator office paper & $<0.0001$ & $<0.0002$ & $<0.002$ \\
\hline Laser color DIP handsheet & $<0.0001$ & $<0.0002$ & $<0.002$ \\
\hline Laser black DIP handsheet & $<0.0001$ & $<0.0002$ & $<0.002$ \\
\hline Ink Jet DIP handsheet & $<0.0001$ & $<0.0002$ & $<0.002$ \\
\hline
\end{tabular}

Tab. 2. Amounts of metal ions determined in cold-water extracts (DIPdeinked pulp)

As shown in the Table 2, all detected amounts of metal ions were actually found below the quantification limit of the instrument, which leads to the conclusion that there is no danger whatsoever of a migration of these compounds from the paper samples into the food.

The amounts of polychlorinated biphenyls (PCB) and primary aromatic amines determined in solvent extracts of tested paper samples are presented in Table 3 .

According to the Croatian Ordinance on sanitary safety of materials and articles intended to come into direct contact with foodstuffs, finished products must not contain more than $2 \mathrm{mg}$ of PCB per kg paper. On the other hand, German BfR Recommendations do not impose the testing of PCBs in finished paper, so no limits for PCBs are set within the existing German regulation.

Furthermore, according to the German BfR Recommendations, primary aromatic amines must not be detectable in the extract of the finished product. However, the detection limit still has to be defined. On the other hand, the Croatian Ordinance requires that the content of these substances must be below the limit of detection which is set to $0.1 \mathrm{mg}$ of primary aromatic amines per $\mathrm{kg}$ of paper. Testing is not required for paper and board intended to come into contact with dry, non-fatty foodstuffs.

The results of the detected amounts of polychlorinated biphenyls (PCB) and primary aromatic amines in solvent extracts (Table 3) show that all detected concentrations of analysed compounds were also below the quantification limit of the instrument. With regard to these three food contact suitability parameters, all tested papers are considered suitable for a direct contact with food.

\begin{tabular}{|c|c|c|}
\hline Amount in solvent extract & PCB & $\begin{array}{c}\text { Primary aromatic } \\
\text { amines }\end{array}$ \\
\hline & \multicolumn{2}{|c|}{$\mathrm{mg} / \mathrm{kg}$ paper } \\
\hline Limit & 2 & 0.1 \\
\hline Navigator office paper & $<0.02$ & $<0.05$ \\
\hline Laser color DIP handsheet & $<0.02$ & $<0.05$ \\
\hline Laser black DIP handsheet & $<0.02$ & $<0.05$ \\
\hline Ink Jet DIP handsheet & $<0.02$ & $<0.05$ \\
\hline
\end{tabular}

Tab. 3. Amounts of PCBs and primary aromatic amines in solvent extracts (DIP- deinked pulp)

The results of diisopropylnaphthalene (DIPN) and total phthalate content determination are presented in Table 4. From these series of analyses, the original office paper Navigator has been excluded since the virgin fibre papers do not require analysis on the presence of DIPNs and phthalates, as they are commonly found only in recycled paper pulp.

\begin{tabular}{|l|c|c|}
\hline Amount in solvent extract & DIPN & $\begin{array}{c}\text { Total phthalate } \\
\text { content }\end{array}$ \\
\hline & \multicolumn{2}{|c|}{$\mathrm{mg} / \mathrm{kg}$ paper } \\
\hline Laser color DIP handsheet & $<0.5$ & 5.9 \\
\hline Laser black DIP handsheet & $<0.5$ & 5.3 \\
\hline Ink Jet DIP handsheet & $<0.5$ & 12.5 \\
\hline
\end{tabular}

Tab. 4. DIPN content and total phthalate content in solvent extracts of papers (DIP - deinked pulp)

The presented results indicate that DIPNs were not detected in any of the analyzed samples as the concentrations of DIPNs were actually below the detection limit. This result was expected since the presence of DIPN in recycled paper originates from the use of recovered paper grades that include carbonless copy paper and thermal paper from office waste in which DIPN is used as solvent for the ink system. However, the results of total phthalate content determination indicate that phthalates were found in all deinked pulp handsheets in the range of $5.3-12.5 \mathrm{mg} / \mathrm{kg}$ paper.

Regarding the regulations related to the residual amounts of phthalates in food contact paper, the permitted limit of the total phthalate content in paper material, expressed as a group restriction, was found in the Nordic guideline, whereas in the German and Croatian regulations the restriction limits were set only for individual phthalates. Hence, the Nordic reference was used for the interpretation of obtained results. The Nordic guideline imposes that the level of total phthalate content should not exceed the limit of $0.25 \mathrm{mg}$ of phthalates per $\mathrm{dm}^{2}$ of paper. Since in this case the limitation for the residual phthalate content in paper material is expressed in weight/area units, whereas the results obtained by an analytical measurement provided the weight/weight results, a conversion to weight/area units had to be done.

The conversion was done by taking into account the actual grammage of analysed paper (Equation 1) 


$$
Q a=\frac{Q m G}{100000}
$$

Where:

$Q a$ is concentration of substance in paper expressed as $\mathrm{mg} / \mathrm{dm}^{2}$, $\mathrm{Qm}$ is concentration of substance in paper expressed as $\mathrm{mg} / \mathrm{kg}$, $G$ is grammage of paper as expressed as $\mathrm{g} / \mathrm{m}^{2}$.

The results of a total phthalate content present in analysed handsheets expressed as $\mathrm{mg} / \mathrm{dm}^{2}$ of material are presented in Table 5.

\begin{tabular}{|c|c|c|}
\hline Amount in solvent extract & $\begin{array}{c}\text { Grammage } \\
\left(\mathrm{g} / \mathrm{m}^{2}\right)\end{array}$ & $\begin{array}{l}\text { Total phthalate } \\
\text { content } \\
\left(\mathrm{mg} / \mathrm{dm}^{2}\right)\end{array}$ \\
\hline & \multicolumn{2}{|r|}{$0.25 \mathrm{mg} / \mathrm{dm}^{2}$} \\
\hline Laser color DIP handsheet & 60 & 0.00354 \\
\hline Laser black DIP handsheet & 60 & 0.00318 \\
\hline Ink Jet DIP handsheet & 60 & 0.00750 \\
\hline
\end{tabular}

The results of residual phthalate content in tested papers, show that all detected levels of phthalates in the analysed handsheets are found much lower than the maximum permitted limit $(<0.25 \mathrm{mg} / \mathrm{dm} 2)$. Therefore, it can be concluded that all analysed papers, according to this food contact suitability parameter, are considered suitable to be used in direct contact with food.

As office paper grades usually contain high amounts of fluorescent whitening agents (FWA), the bleed fastness of FWAs was determined. BfR Recommendations and Croatian Ordinance prescribe that FWAs must not migrate into food. Testing is not necessary for paper and board intended to come into contact with dry, non-fatty foodstuffs.

The original paper sample, as well as the deinked handsheets formed after flotation of all printed samples, were subjected to the bleed fastness analysis and only the original paper showed very severe bleeding of the fluorescent whitening agents. Therefore, all analysed handsheet samples are found suitable to be used in direct contact with foods.

\section{CONCLUSIONS}

The conducted research showed that of all analysed contaminants in the deinked pulp handsheets, only the phthalates were detected in concentrations between 5.3 up to $12.5 \mathrm{mg} / \mathrm{kg}$ of paper. While comparing the detected amounts of phthalates in the analysed handsheets to the quantitative restrictions laid down in the German or Croatian regulations, it was impossible to estimate whether those levels of chemicals impose a risk to human health due to the incomplete and imprecise regulations. However, when compared to the maximum limit proposed within the Nordic report on paper and board food contact materials, all the concentrations found were much below the Nordic guideline proposed limits. Moreover, other evaluated contaminants, such as heavy metals $(\mathrm{Cd}, \mathrm{Pb}$ and $\mathrm{Hg})$, primary aromatic amines, polychlorinated biphenyls (PCB) and diisopropylnaphthalenes (DIPN) could not be quantified by available analytical methods i.e. were found at extremely low concentrations.

Regarding the fastness of fluorescent whitened papers, the obtained results indicate that only the original office paper sample showed very severe bleeding of fluorescent whitening agents, while the deinked pulp handsheets showed no bleeding at all and thus are considered suitable to be used in direct contact with food.

It can therefore be concluded that all tested papers regarding the analyses done within this research are found suitable to be used in direct contact with food. Moreover, the office print-outs can be considered suitable alternative raw material in production of white top plies of food packaging linerboards.

\section{ACKNOWLEDGEMENTS}

The authors wish to thank Dr. Bogomil Breznik and Dr. Vera Rutar from the Pulp and Paper Institute, Ljubljana, Slovenia for providing the laboratory deinking flotation trials and also to Dr. Jasna Bosnir and Lidija Barusic from the "Dr. Andrija Stampar" Institute of Public Health, Zagreb, Croatia for providing the food contact analyses.

\section{REFERENCES}

[1] Faul, A.: Deinking and printing: not always on the same team. paper in printing processes. COST E32 Symposium, Grenoble, 2007; Available from: http://www.ingede.com/ingindxe/pdf/2007coste32-faul-team.pdf Accessed: 2010-01-10

[2] Blasius, K., Manoiu, A. (2010). Improving the cost-effectiveness of white top linerboard based on recycled pulp. Cellulose chemistry and technology. 44, 10; 489-497, 2010

[3] Carré, B., Magnin, L.: Digital prints: a survey of the various deinkability behaviours, 7th Research Forum on Recycling. PAPTAC - TAPPI, 2004; Available from http://www.ingede.com/ingindxe/pdf/2004-paptac-digideink-ctpbc-lm.pdf Accessed: 2010-01-15

[4] Paulapuro, H. (2000). Paper and Board Grades, Fapet Oy, ISBN 952-5216-18-7, Helsinki, Finland

[5] Moore, G; O'Hear, J. (2008) Paper's future role, Available from: http://www.chromatographyonline.com/lcgc/data/articlestandard// paper360/172008/512084/article.pdf Accessed: 2012-08-10

[6] Regulation (EC) No 1935/2004 of the European Parliament and of the Council on materials and articles intended to come into contact with food and repealing Directives 80/590/EEC and 89/109/EEC, Official Journal of the European Union, L 338, 4-17 (2004)

[7] BfR, 2009, XXXVI. Papiere, Kartons und Pappen für den Lebensmittelkontakt, Bundesinstitut für Risikobewertung, 2009 Available at http://bfr.zadi.de/kse/faces/resources/pdf/360.pdf Accessed: 2012-08-10

[8] von Wright, A.: Safety assessment of paper and board used in food packaging, in K. A. Barnes et al. (ed.) Chemical migration and food contact materials, Woodhead Publishing Limited, Cambridge, England 2007, p 334

[9] Croatian Ordinance on sanitary safety of materials and articles intended to come into direct contact with foodstuffs, Official Gazette, No. 125, 2009

[10] Nordic report on Paper and Board Food Contact Materials, TemaNord 2008:515, ISBN 978-92-893-1657-6, 2008

[11] TAPPI T $205 \mathrm{sp}-95$ Forming handsheets for physical tests of pulp $(1995$

[12] EN 645:1993 Paper and board intended to come into contact with foodstuffs - Preparation of cold water extract (1993)

[13] EN 12497:2005 Paper and board intended to come into contact with foodstuffs. Determination of mercury in an aqueous extract (2005)

[14] EN 12498:2005 Paper and board intended to come into contact with foodstuffs. Determination of cadmium and lead in an aqueous extract (2005)

[15] ISO 15318:1999 Pulp, paper and board. Determination of 7 specified polychlorinated biphenyls

[16] EN 14719:2005 Pulp, paper and board. Determination of the diisopropylnaphthalene (DIPN) content by solvent extraction (2005)

[17] HR EN 648:2002 Paper and board intended to come into contact with foodstuffs - Determination of the fastness of fluorescent whitened paper and board (2002) 